\title{
An Epidemiological Survey on Awareness towards Orthodontic Treatment in South Indian School Children
}

\author{
Dr. Roopa Siddegowda ${ }^{1, *}$, Dr. Rani. M.S ${ }^{2}$ \\ ${ }^{1}$ Research Scholar, Vokkaligara Sangha Dental College \& Hospital, Rajiv Gandhi University of Health Sciences, Bangalore 560004, \\ Karnataka, India \\ ${ }^{2}$ Professor \& Head, Research Scholar, Vokkaligara Sangha Dental College \& Hospital, Rajiv Gandhi University of Health Sciences, \\ Bangalore 560004, Karnataka, India \\ *Corresponding Author: roopagowda@ymail.com
}

Copyright @ 2013Horizon Research Publishing All rights reserved.

\begin{abstract}
Awareness of malocclusion and the need to make corrections has increasingly become prevalent among our population. As growing public interest in oral health increased, the demand for orthodontic treatment also became more noticeable in dental practices. Enhancing appearance and improving psychosocial status have been identified as important motivating factors behind the decision to initiate orthodontic treatment. This survey was formulated to investigate the awareness of children towards Orthodontic treatment and to create awareness of orthodontic treatment among the children.
\end{abstract}

Keywords Awareness, Malocclusion, School children, Questionnaire, Epidemiological Survey, Karnataka, South India

\section{Introduction}

Oral health can affect the general health, well-being, education and development of children. In many of the countries, large number of parents and children are unaware of the knowledge about the causes, occurrence and prevention of most of the common oral diseases. One of the most common dental problems in mankind along with dental caries, gingival disease, and dental fluorosis is malocclusion [1]. Malocclusion can be defined as an occlusion in which there is mal-relationship between the arches in any of the planes or there are anomalies in tooth position beyond the normal limits. The etiology of malocclusion can be genetic or environmental and or a combination of both along with various local factors such as oral habits, tooth anomalies etc. The malocclusion has been shown to affect oral health, increase prevalence of caries and can cause temporo-mandibular disorders. The benefits of orthodontic treatment are prevention of tissue damage, improvement in aesthetics and physical function. The uptake of orthodontic treatment is influenced by the desire to look attractive, self-esteem and self -perception of dental appearance [2]. Awareness is the state or quality of being aware of something. In every country, there is a need to identify the awareness levels of children with respect to oral health and the orthodontic treatment as children play an important role in inculcating healthy lifestyle practices to last for a lifetime. Pre-adolescents and adolescents would be benefitted with the knowledge about orthodontic treatment since early orthodontic treatment could be advantageous in preventing further malocclusion complications. Furthermore, knowledge about age related patient concerns may guide and assist the orthodontist in educating potential patients and their parents and in providing advice.

There are no reported studies to assess the awareness of Orthodontic treatment in South Indian school children. In this context, the objective of the present epidemiological survey was to record the awareness of orthodontic treatment in school children of Karnataka.

\section{Materials and Methods}

With a prior permission from the Ministry of Higher Primary and Secondary Education Board of Karnataka, India, a survey was planned in the schools. The survey was carried out in selected schools in all the district head quarters. Children in the age group of 10-16 years were included in the study and constituted the study population. Population proportionate technique was employed for sample size estimation. According to the population census 2011, the total population in Karnataka was 61130704 out of which 10-16 years old children constitute 29\% (According to National Family Health Survey-2, India [1998-99], child population in the age group of 10-16 years was taken as a reference). With $95 \%$ confidence level, the estimated sample size was 9505. In each district, schools were selected from a list of schools provided by the Karnataka Higher Primary and Secondary Education Board by lottery method. A total of 102 schools all over Karnataka were surveyed during the 
year 2012-2013. A total sample of 9505 children in the age group of 10-16 years was selected from the randomized schools in each district all over Karnataka. Children who obtained written informed consent from parents to participate in the study were included. Exclusion criteria used were- history of previous orthodontic treatment, rampant caries, multiple missing teeth, mutilated malocclusion and other craniofacial anomalies like cleft lip and palate, facial hemiatropy, cleidocranial dysplasia etc.

Ethical clearance to conduct the survey was obtained from the Vokkaligara Sangha Dental College and Hospital Review and Ethical Committee. Prior permission to conduct the survey was taken from the concerned school authorities.

A pre-structured self-administered questionnaire consisting of 15 questions with multiple answers were given to the children after the clinical examination to assess their knowledge and attitude [awareness] towards Orthodontic treatment. The responses of the children to the questions were recorded on a 3 point Likert scale [a. yes, b. no, c. don't know]. An oral health lecture was given to all the children in the school to create awareness about Dental health and
Orthodontic treatment. The awareness levels were measured in a three point Likert scale as follows.

1- Poor awareness level

2- Moderate awareness level

3- Good awareness level

Table 1. Gender distribution of the sample

\begin{tabular}{|c|c|}
\hline Gender & No of children \\
\hline Male & 4966 \\
\hline Female & 4539 \\
\hline Total & 9505 \\
\hline
\end{tabular}

Table 2. Age distribution of the sample

\begin{tabular}{|c|c|c|c|c|c|c|c|}
\hline $\begin{array}{c}\text { Age / } \\
\text { gender }\end{array}$ & $\begin{array}{c}10 \\
\text { years }\end{array}$ & $\begin{array}{c}11 \\
\text { years }\end{array}$ & $\begin{array}{c}12 \\
\text { years }\end{array}$ & $\begin{array}{c}13 \\
\text { years }\end{array}$ & $\begin{array}{c}14 \\
\text { years }\end{array}$ & $\begin{array}{c}15 \\
\text { years }\end{array}$ & $\begin{array}{c}16 \\
\text { years }\end{array}$ \\
\hline Male & $47 \%$ & $50 \%$ & $52 \%$ & $54 \%$ & $51 \%$ & $52 \%$ & $64 \%$ \\
\hline Female & $53 \%$ & $50 \%$ & $48 \%$ & $46 \%$ & $49 \%$ & $48 \%$ & $36 \%$ \\
\hline
\end{tabular}

Table 3. Questionnaire format to analyze the Awareness of children towards orthodontic treatment

\begin{tabular}{|c|c|c|}
\hline $\begin{array}{c}\text { Awareness about } \\
\text { Dentist/ Orthodontist }\end{array}$ & $\begin{array}{c}\text { 1. Are you aware of a dentist? } \\
\text { 2. Have you visited a dentist before? }\end{array}$ & $\begin{array}{c}\text { a. Yes, } \\
\text { b. No, } \\
\text { c. Don't know }\end{array}$ \\
\hline $\begin{array}{c}\text { Knowledge about } \\
\text { irregular teeth }\end{array}$ & $\begin{array}{c}\text { 6. Do you believe teeth should be properly aligned for a better facial appearance? } \\
\text { 7. Do you know crooked teeth have ill effects? }\end{array}$ & $\begin{array}{c}\text { a. Yes, } \\
\text { b. No, } \\
\text { c. Don't know }\end{array}$ \\
\hline $\begin{array}{c}\text { Knowledge about } \\
\text { Orthodontic treatment }\end{array}$ & $\begin{array}{c}\text { 13. Did you know taking braces treatment at an earlier age would improve facial appearance? } \\
\text { 14. Do you know the duration for braces treatment is longer than other dental procedures? } \\
\text { 15. Do you know that orthodontic treatment is costly? }\end{array}$ & $\begin{array}{c}\text { a. Yes, } \\
\text { b. No, } \\
\text { c. Don't know }\end{array}$ \\
\hline $\begin{array}{c}\text { Awareness about braces/ } \\
\text { Orthodontic treatment }\end{array}$ & 8. Have you seen people wearing braces? 9. Have you ever felt the need to wear braces? & $\begin{array}{c}\text { a. Yes, } \\
\text { b. No, } \\
\text { c. Don't know }\end{array}$ \\
\hline
\end{tabular}

\section{Result}

Table 4. Awareness towards orthodontic treatment in boys and girls.

\begin{tabular}{|c|c|c|c|c|c|c|c|c|c|c|}
\hline \multirow{3}{*}{ Gender } & \multicolumn{10}{|c|}{ Awareness of orthodontic treatment } \\
\hline & \multicolumn{2}{|c|}{$\begin{array}{l}\text { Awareness of } \\
\text { Dentist/ } \\
\text { Orthodontist }\end{array}$} & \multicolumn{2}{|c|}{$\begin{array}{l}\text { Knowledge about } \\
\text { Irregular teeth }\end{array}$} & \multicolumn{2}{|c|}{$\begin{array}{c}\text { Knowledge about } \\
\text { Orthodontic } \\
\text { treatment }\end{array}$} & \multicolumn{2}{|c|}{$\begin{array}{l}\text { Awareness of Braces } \\
\text { treatment }\end{array}$} & \multicolumn{2}{|c|}{ Total } \\
\hline & Mean & S.D & Mean & S.D & Mean & S.D & Mean & S.D & Mean & S.D \\
\hline Boys & 2.27 & 1.56 & 3.09 & 1.36 & 1.23 & 1.05 & 1.63 & 0.90 & 8.21 & 2.96 \\
\hline Girls & 2.23 & 1.06 & 3.15 & 1.40 & 1.20 & 1.06 & 1.64 & 0.88 & 8.22 & 2.98 \\
\hline $\mathrm{T}$ test & \multicolumn{2}{|c|}{1.57} & \multicolumn{2}{|c|}{-2.14} & \multicolumn{2}{|c|}{1.34} & \multicolumn{2}{|c|}{-0.72} & \multicolumn{2}{|c|}{-0.17} \\
\hline $\operatorname{Sig}(2$-tailed) test & \multicolumn{2}{|c|}{.115} & \multicolumn{2}{|c|}{.032} & \multicolumn{2}{|c|}{.179} & \multicolumn{2}{|c|}{.466} & \multicolumn{2}{|c|}{.861} \\
\hline
\end{tabular}




\subsection{Awareness of Dentist/ Orthodontist}

The mean awareness about Dentist and Orthodontist in boys is $2.27+/-1.56$ and girls are $2.23+/-1.06$. When the awareness of Dentist and Orthodontist is compared among the boys and girls using ' $t$ ' test, the results were not significant statistically i.e 1.57 ( $\mathrm{P}$ value $>0.05$ ) as shown in the table.

\subsection{Knowledge about Irregular Teeth}

The mean knowledge about irregular teeth in boys is $3.09+/ 1.36$ and girls are 3.15+/-1.40. When the knowledge about irregular teeth is compared among the boys and girls using ' $t$ ' test, the results were significant statistically i.e -2.14 ( $\mathrm{P}$ value $<0.05$ ) as shown in the table.

\subsection{Knowledge about Orthodontic Treatment}

The mean knowledge about Orthodontic treatment in boys is $1.23+/-1.05$ and girls are $1.20+/-1.06$. When the knowledge about Orthodontic treatment is compared among the boys and girls using ' $\mathrm{t}$ ' test, the results were not significant statistically i.e 1.34 ( $\mathrm{P}$ value $>0.05)$ as shown in the table.

\subsection{Awareness of Braces Treatment}

The mean awareness about braces treatment in boys is $1.63+/-0.90$ and girls are $1.64+/-0.88$. When the awareness of braces treatment is compared among the boys and girls using ' $\mathrm{t}$ ' test, the results were not significant statistically i.e -0.72 ( $\mathrm{P}$ value $>0.05$ ) as shown in the table.

\subsection{Awareness of Dentist/ Orthodontist}

One-way ANOVA reveals' a significant difference among the mean scores of awareness about Dentist and Orthodontist among the age groups of the children. F value of 2.38 was found to be significant at .026 levels. Scheffe's post hoc-test indicates that mean awareness of 10 year old children is 2.21 , 11 year children is $2.30,12$ year children is $2.28,13$ year children is $2.21,14$ year children is $2.20,15$ year children is 2.28 and 16 year children is 2.28 .

\subsection{Knowledge about Irregular Teeth}

One-way ANOVA reveals' a significant difference among the mean scores of knowledge about irregular teeth among the age groups of the children. F value of 11.02 was found to be significant at .000 levels. Scheffe's post hoc-test indicates that 11 year old children have a lesser knowledge (2.94), 16 year old children have a higher knowledge (3.28) and the remaining age group children have a moderate knowledge.

\subsection{Knowledge about Orthodontic Treatment}

One-way ANOVA reveals' a significant difference among the mean scores of knowledge about orthodontic treatment among the age groups of the children. F value of 2.17 was found to be significant at .043 levels. Scheffe's post hoc-test indicates that 10 year old children have a lesser knowledge (1.14), 15 and 16 year old children have a higher knowledge of (1.27).

Table 5. Awareness towards orthodontic treatment in 10-16 years age group of children

\begin{tabular}{|c|c|c|c|c|c|c|c|c|c|c|}
\hline \multirow{3}{*}{ Age groups } & \multicolumn{10}{|c|}{ Awareness of orthodontic treatment } \\
\hline & \multicolumn{2}{|c|}{$\begin{array}{c}\text { Awareness of Dentist/ } \\
\text { Orthodontist }\end{array}$} & \multicolumn{2}{|c|}{$\begin{array}{l}\text { Knowledge about Irregular } \\
\text { teeth }\end{array}$} & \multicolumn{2}{|c|}{$\begin{array}{c}\text { Knowledge about } \\
\text { Orthodontic treatment }\end{array}$} & \multicolumn{2}{|c|}{$\begin{array}{c}\text { Awareness of } \\
\text { Braces treatment }\end{array}$} & \multicolumn{2}{|c|}{ Total } \\
\hline & Mean & S.D & Mean & S.D & Mean & S.D & Mean & S.D & Mean & S.D \\
\hline 10 & $2.21^{\mathrm{a}}$ & 1.10 & $3.10^{\mathrm{bc}}$ & 1.42 & $1.14^{\mathrm{a}}$ & 1.09 & $1.65^{\mathrm{abc}}$ & 0.94 & $8.00^{\mathrm{a}}$ & 3.18 \\
\hline 11 & $2.30^{\mathrm{a}}$ & 1.09 & $2.94^{\mathrm{a}}$ & 1.44 & $1.21^{\mathrm{a}}$ & 1.08 & $1.82^{\mathrm{abc}}$ & 0.92 & $8.06^{\mathrm{ab}}$ & 3.16 \\
\hline 12 & $2.28^{\mathrm{a}}$ & 1.09 & $3.04^{\mathrm{ab}}$ & 1.42 & $1.16^{\mathrm{ab}}$ & 1.05 & $1.71^{\mathrm{abc}}$ & 0.93 & $8.13^{\mathrm{ab}}$ & 3.11 \\
\hline 13 & $2.21^{\mathrm{a}}$ & 1.03 & $3.20^{\mathrm{cd}}$ & 1.34 & $1.22^{\mathrm{ab}}$ & 1.05 & $1.50^{\mathrm{ab}}$ & 0.90 & $8.28^{\mathrm{abc}}$ & 2.86 \\
\hline 14 & $2.20^{\mathrm{a}}$ & 1.03 & $3.25^{\mathrm{d}}$ & 1.31 & $1.24^{\mathrm{ab}}$ & 1.03 & $1.42^{\mathrm{a}}$ & 0.86 & $8.31^{\mathrm{bc}}$ & 2.73 \\
\hline 15 & $2.28^{\mathrm{a}}$ & 1.04 & $3.19^{\mathrm{cd}}$ & 1.34 & $1.27^{\mathrm{b}}$ & 1.07 & $1.67^{\mathrm{abc}}$ & 0.87 & $8.37^{\mathrm{bc}}$ & 2.86 \\
\hline 16 & $2.28^{\mathrm{a}}$ & 1.00 & $3.28^{\mathrm{d}}$ & 1.38 & $1.27^{\mathrm{b}}$ & 1.05 & $1.64^{\mathrm{abc}}$ & 0.85 & $8.45^{\mathrm{c}}$ & 2.91 \\
\hline Total & 2.25 & 1.06 & 3.12 & 1.38 & 1.21 & 1.06 & 1.64 & 0.90 & 8.21 & 2.97 \\
\hline F value & \multicolumn{2}{|c|}{2.38} & \multicolumn{2}{|c|}{11.02} & \multicolumn{2}{|c|}{2.17} & \multicolumn{2}{|c|}{.914} & \multicolumn{2}{|c|}{2.95} \\
\hline$P$ value & \multicolumn{2}{|c|}{.026} & \multicolumn{2}{|c|}{.000 (HS) } & \multicolumn{2}{|c|}{.043} & \multicolumn{2}{|c|}{.484} & \multicolumn{2}{|c|}{.007} \\
\hline
\end{tabular}

*Note: F-Fisher's Value; P-Probability; HS-Highly significant; dfs=6, 9498. Means with different superscripts are significantly different from each other as indicated by Scheffe's Post hoc test (Alpha=.05). 


\subsection{Awareness of braces treatment}

One-way ANOVA reveals' a significant difference among the mean scores of awareness about braces treatment among the age groups of the children. F value of .914 was found not significant at .484 levels. Scheffe's post hoc-test indicates that 10 year old children have a lesser knowledge (1.56), 16 year old children have a higher knowledge (1.63) and the remaining age group children have a moderate knowledge.

\section{Discussion}

Globally, there has been an increase in awareness of Orthodontics as a dental specialty in children as well as adults [3]. A similar trend has been reported in Nigeria with an associated increase in Orthodontic care [4]. In a developing country like India, malocclusion is still not considered to be a dental problem because more priority is given to the treatment of dental caries and periodontal diseases due to pain experienced by them. Most malocclusion cases are still not treated properly due to ignorance of patients, parents, inadequacy of resources, lack of knowledge about malocclusion and other influencing factors like literacy rate and socio-economic status. The level of dental health knowledge, positive dental health attitude, and dental health behavior are interlinked and associated with the level of education and income as demonstrated by studies in the past $[5,6,7,8,9,10]$. Attitudes and perceptions towards dental appearance differ among populations and among individuals [11]. Although age-related changes in malocclusion concerns ideally should be studied longitudinally, the present study allowed comparison between different age groups by means of a cross-sectional study. Such a study can give an indication of changing attitudes toward malocclusion with age. Karnataka is one of the major states of South India and ninth largest state in India in terms of Population. Malocclusion has an impact on the social and the psychological behavior of an individual, hence knowledge on how individuals perceive and react to malocclusion in a community is necessary for effective orthodontic treatment and care.

Both boys and girls exhibited same level of awareness in relation to Orthodontic treatment as shown in Table 4.

LI Jing et al [12] in his study stated that the orthodontic awareness level was unsatisfactory and the correlation between the awareness level and malocclusion problems was poor. Our survey is in disagreement with this, revealing that the children had a moderate level of awareness about malocclusion. Bhavneet Kaur [13] studied the level of dental awareness in parents of pre-school children in the Indian context which revealed a poor level of dental awareness in those parents. In our survey, we found a moderate awareness in children towards dental awareness.
The following were the conclusions drawn from the survey.

1. The school children exhibited a moderate level of awareness about Dentist and Orthodontist and knowledge about irregular teeth.

2. The school children had less awareness about Orthodontic treatment.

3. Both boys and girls showed same levels of awareness regarding Orthodontic treatment.

\section{REFERENCES}

[1] Dhar V, Jain A, Van Dyke T E , Kohli A. Prevalence of gingival diseases, malocclusion and fluorosis in school-going children of rural areas in Udaipur district. Journal of the Indian Society of Pedodontics and Preventive Dentistry 2007; 25:103-105.

[2] Mandeep Kaur Bhullar, Ashutosh Nirola Malocclusion Pattern In Orthodontic Patients. Indian Journal of Dental Sciences 2012; 4: 4, 20-22.

[3] Anitha G, Asiya B. Adult Orthodontics IJDA 2010; 2: 96-99

[4] Dacosta ON. The prevalence of malocclusion among a population of northern Nigerian school children. West African J Med. 1999; 18: 91-96.

[5] Chen MS. Children's preventive dental behavior in relation their mothers' socioeconomic status, health beliefs and dental behaviors. J DentChild1986; 53:105-9.

[6] Al-Wahadni A M, Al-Omiri MK, Kawamura M. Differences in self-reported oral health behavior between dental students and dental technology/dental hygiene students in Jordan. J Oral Sciences 2004; 46:191-7.

[7] Kawamura M, Iwamoto Y, Wright FA. A comparison of self-reported dental health attitudes and behavior between selected Japanese and Australian students. J Dent Education 1997; 61:354- 60 .

[8] Barrieshi-Nusair K, Alomari Q, Said K. Dental health attitudes and behavior among dental students in Jordan. Community Dent Health 2006; 23:147-51.

[9] Kawamura M, Spadafora A, Kim KJ, Komabayashi T. Comparison of United States and Korean dental hygiene students using hiroshima university-dental behavioral inventory (HU-DBI). Int Dent J 2002; 52:156-62.

[10] Hamilton ME, Coulby WM. Oral health knowledge and habits of senior elementary school students. J Public Health Dent 1991; 51: 212-9.

[11] Vallittu P, Vallittu A, Lassila V: Dental aesthetics-a survey of attitudes in different groups of patients. Journal of Dentistry 1996, 24(5):335-338.

[12] Bhavneet Kaur. Evaluation of oral health awareness in parents of preschool children. Indian Journal of Dental Research 2009: Volume 20; Issue 4, Page 463-465.

[13] Tulloch JFC, Shaw WC, Smith A. A comparison of attitudes towards orthodontic treatment in British and American communities. Am J Orthod 1984; 85:253-259.

\section{Conclusion}

